\title{
PLANKTON COMMUNITY STRUCTURE ON FISH PONDS IN THE RIAM KANAN RIVER OF BANJAR REGENCY
}

\author{
${ }^{1}$ Rieski Ambarwati, ${ }^{1}$ Krisdianto, ${ }^{2}$ Slamat \\ ${ }^{1}$ Biology Study Program, Mathematics and Natural Science Faculty \\ ${ }^{2}$ Aquaculture Study Program, Fisheries and Marine Faculty \\ Lambung Mangkurat University, Banjarbaru, South Kalimantan, Indonesia \\ E-mail: rieski ambarwati@yahoo.co.id
}

\begin{abstract}
Aquaculture in Riam Kanan river receives water supply from rivers and Riam Kanan reservoir from upstream to downstream and practices different irrigation and fertilization systems. This study was aimed to compare the plankton community structure, to find out the physicalchemical parameters associated with the abundance of plankton and the fertility of the fish-farming ponds. The research was conducted at Mandiangin Freshwater Aquaculture Center (Balai Budidaya Air Tawar - BBAT), Karang Intan (Balai Benih dan Induk Ikan Air Tawar - BB-IAT) and Cindai Alus Minapolitan area by using the observation method. Water samples were taken by composite of 6 replicates at 12 stations. The parameters measured were temperature, visibility, $\mathrm{pH}$, iron, free ammonia, nitrate, phosphate, DO, BOD and plankton analysis. Data were tested statistically with cluster, Pearson correlation and regression. The result shows that there are differences in plankton community structure in the fish ponds, shown by 5 cluster groups. The abundance of phytoplankton has a significant correlation with $\mathrm{pH}$, temperature, DO, and free ammonia. The abundance of zooplankton also has a significant correlation with $\mathrm{pH}, \mathrm{DO}, \mathrm{BOD}$, and free ammonia. The seed pond at BBAT Mandiangin is eutrophically dominated by Bacillarophyta and Amoboezoa, while in BB-IAT Karang Intan and Cindai Alus are dominated by Cyanophyta and Rotifera. The inlet channel of BB-IAT Karang Intan and the broodstock pond belong to mesotrophic category, predominance by Cyanophyta, Chlorophyta and Rotifer. BBIAT Karang Intan outlet ponds, BBAT Mandiangin inlet channel and Cindai Alus inlet pond are included in the oligotrophic category, predominance by Cyanophyta and Chlorophyta. Plankton community structure of the fishfarming pond varies even with the same ecological conditions.
\end{abstract}

Keywords: fish-farming pond, plankton, Riam Kanan, community structure

\section{INTRODUCTION}

BBAT Mandiangin and BB-IAT Karang Intan use a parallel system to irrigate their ponds. Whereas the Cindai Alus fish-farming ponds using a series system, from water channels into a pond and then flow into other ponds. Fertilization happens only in the seeds pond with the aim of increasing the abundance and diversity of plankton as the natural food of fish seeds. Differences in the location and management of fish-farming ponds certainly affect the structure of phytoplankton and zooplankton communities.

This study was aimed to compare the structure of the plankton community, to find out the physical-chemical parameters associated with plankton abundance and the fertility of the fish-farming ponds.

\section{MATERIALS AND METHODS}

This study was conducted at BBAT Mandiangin, BBI-IAT Karang Intan, and Cindai Alus Minapolitan area of Banjar Regency, South Kalimantan in March 2017. The sample analysis was conducted in the Mathematics and Natural Sciences Faculty Basic Laboratory, Lambung Mangkurat University, Banjarbaru.

The sampling locations were determined using a purposive method, taking into account the location of fish-farming activities scattered along the Riam Kanan reservoir channel. Each location was assigned with four water sampling points. Repeat sampling were done 6 times at each point. Plankton samples were taken by filtering 24 liters of water using a plankton net. All plankton samples were preserved with $5 \%$ lugol acid solution.

The parameters analyzed in this study were the phytoplankton and zooplankton community structure, temperature, $\mathrm{pH}$, and visibility were measured in situ; iron, free ammonia, nitrate, phosphate by spectrophotometry; DO and BOD was measured using electrode method. Plankton samples were observed with a phase contrast microscope on Sedgwick Rafter's whole 
chamber field of view. Identification of plankton was done with plankton identification books from: Edmondson (1959); Bellinger \& Sigee (2010); Patten et al. (2012); Witty (2004); Vuuren et al. (2006); Phan-doang-dang et al. (2015); journals: Da Silva \& Tamanaha (2008), Kouassi et al. (2015), Ray \& Pal (2015), Srivastava et al. (2014); and other referrals from the internet.

The structures of phytoplankton and zooplankton community are known from their abundance level (Dhargalkar and Ingole, 2004), diversity index (Shannon-Wiener), dominance index (Simpson) and uniformity index (Evenness). From the obtained abundance data on phytoplankton and zooplankton (per division/phylum), cluster analysis was done to find out the object group based on the characteristics similarity among the objects. The method used was a hierarchical method. The correlation between plankton abundance and physical-chemical parameters was explained by Pearson correlation analysis and regression equations.

\section{RESULTS AND DISCUSSION}

\section{The Plankton Community Structure}

Based on the results of the study, the plankton composition in fish-farming ponds from 12 sampling points, 7 phytoplankton divisions were found: Bacillarophyta (30 genera), Chlorophyta (49 genera), Cryptophyta (2 genera), Cyanophyta (16 genera), Dynophyta (2 genera), Euglenophyta (5 genera), and Ochrophyta (1 genus). Zooplankton consists of 5 phyla, namely: Amoebozoa (11 genera), Arthropoda, Ciliophora (4 genera), Nematodes ( 1 order), and Rotifera (22 genera). The phylum of Arthropoda includes the Anostraca, Calanoida, Cyclopoida, Cladocera, Acari, and Ostracoda groups. The Diversity (D) and Uniformity (E) indexes of phytoplankton and zooplankton from the fish-farming ponds are presented in Table 1 below.

Table 1. Diversity Index (H'), Dominance (D) and Uniformity (E) of phytoplankton and zooplankton from fish-farming ponds at each observation point

\begin{tabular}{lccccccccccccc}
\hline & \multicolumn{4}{c}{ BBAT Mandiangin } & \multicolumn{4}{c}{ BBIAT Karang Intan } & \multicolumn{4}{c}{ Cindai Alus } \\
\cline { 2 - 14 } Index & 1A & 1B & 1C & 1D & 2A & 2B & 2C & 2D & 3A & $3 \mathrm{~B}$ & $3 \mathrm{C}$ & 3D \\
\hline H' phyto & 1.29 & 1.57 & 0.33 & 1.69 & 0.71 & 1.23 & 2.18 & 2.32 & 2.75 & 1.72 & 1.66 & 2.18 \\
D phyto & 0.40 & 0.40 & 0.89 & 0.30 & 0.75 & 0.36 & 0.23 & 0.14 & 0.13 & 0.22 & 0.26 & 0.24 \\
E phyto & 0.45 & 0.37 & 0.10 & 0.52 & 0.24 & 0.54 & 0.55 & 0.71 & 0.71 & 0.51 & 0.50 & 0.57 \\
H' zoo & 2.40 & 2.31 & 2.85 & 1.52 & 1.56 & 1.51 & 1.21 & 1.61 & 1.89 & 1.87 & 1.77 & 1.94 \\
D zoo & 0.08 & 0.13 & 0.11 & 0.25 & 0.15 & 0.25 & 0.3 & 0.11 & 0.12 & 0.21 & 0.22 & 0.19 \\
E zoo & 0.97 & 0.88 & 0.83 & 0.85 & 0.97 & 0.63 & 0.88 & 1.00 & 0.97 & 0.60 & 0.59 & 0.70 \\
\hline
\end{tabular}

Information:

$1 \mathrm{~A} ; 2 \mathrm{~A} ; 3 \mathrm{~A}=$ Inlets

$1 \mathrm{~B} ; 2 \mathrm{C}=$ Koi seeds ponds

$1 \mathrm{C}=$ Fertilizer Pond (Haruan seeds preparation)

Zooplankton diversity index in each pond $(1.51-2.87)$ are classified in the medium category (between 1-3). There are no toxic materials found in the ponds, supported by the DO levels, which in accordance with the requirements of the class III water quality standard $\left(>3 \mathrm{mg} \mathrm{L}^{-1}\right)$, shown in Table 2 . The diversity index of phytoplankton in is less than 1. The dominant index in the $1 \mathrm{C}$ pond approaches 1 due to the dominance of Pseudoanabaena from the Cyanophyta group. Pseudoanabaena sp. are also found in the Mandiangin BBAT inlet channel $(1 \mathrm{~A})$ in small amount, and in the Koi seeds pond (1B) in considerable amounts. This shows the rapid
$1 \mathrm{D}=$ Outlet (Gurame's broodstock pond) $2 \mathrm{D}=$ Outlet

2B; 3B; 3C = Papuyu's Ponds

$3 \mathrm{D}=$ Outlet (Patin's broodstock pond)

growth of Pseudoanabaena in $1 \mathrm{~B}$ and $1 \mathrm{C}$ ponds. Concentrations of phosphate, free ammonia and nitrates in $1 \mathrm{C}$ pond is high. According to Liu \& Vyverman (2014) Pseudanabaena sp. are efficient to reduce nitrate levels in high nitrogen-containing wastewater (Liu \& Vyverman, 2015). Likewise, the ponds and inlet channel of BB-IAT Karang Intan phytoplankton diversity index are $<1$ due to Cyanophyta dominance from Lyngbia sp. The ponds or inlet channels at BBAT Mandiangin and Cindai Alus have a good diversity index, no dominance by certain types. The diversity index in the BBIAT Karang Intan 
Rieski Ambarwati, Krisdianto, Slamat: Plankton Community Structure on Fish Ponds in The ...

inlet ponds is low due to the dominance of Lyngbiasp.

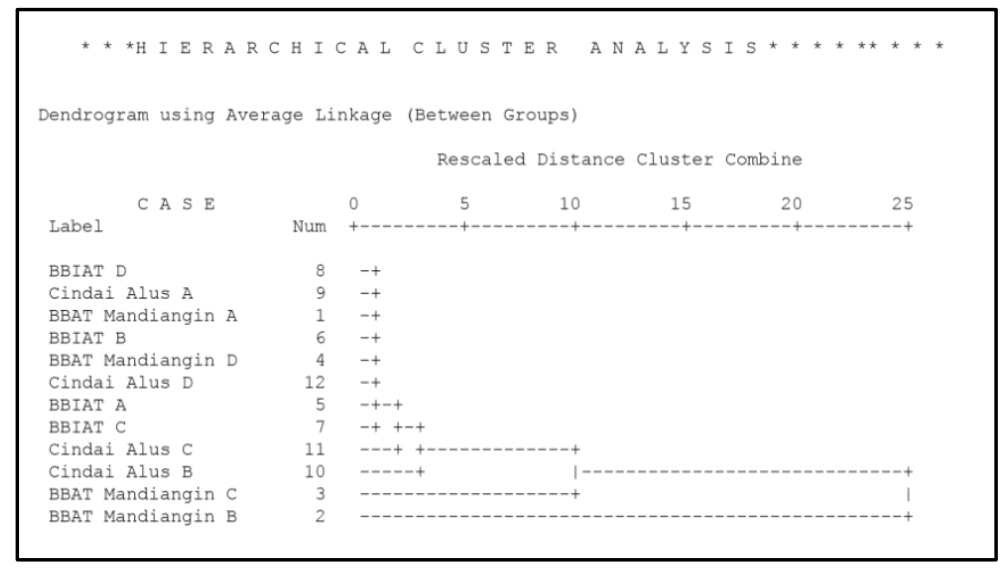

Figure 1. Dendrogram cluster

The cluster analysis divides the ponds into 5 groups. The first group consists of 2D pond (BBIAT Outlet), 3A (Cindai Alus Inlet), 1A (BBAT Inlet), 2B (BBIAT-papuyu's pond), 1D (BBAT outlet/Gurame's broodstock pond), 3D (Cindai Alus outlet/Patin's pond), 2A (BB-IAT Inlet), and 2C (BB-IAT - Koi seeds). While the $3 \mathrm{C}$ pond (Cindai Alus Papuyu's seeds 1), 3B (Cindai Alus Papuyu's seeds 2), 1C (BBAT - fertilizer pond), and 1B (BBAT - Koi seeds) each form its own group. This dendrogram illustrates the similarity of plankton composition in 8 ponds in group one compared to the other ponds, although the ponds are different when viewed from the plankton community structure and the fishes. This is because the considerable distance scale of $1 \mathrm{~B}$ pond with other ponds, so that the distance scale of the first group becomes very close.

\section{Abiotic Factor Relation with Plankton Abundance}

The measurement result of the physical and chemical parameters from the fish-farming ponds from which water samples were examined can be seen in Table 2 .

Pearson correlation test results can be seen on Table 3.

Table 2. Measurement result of the chemical and physical parameters of the fish-farming ponds water

\begin{tabular}{lllllllll}
\hline $\begin{array}{l}\text { Pond } \\
\text { Codes }\end{array}$ & $\begin{array}{l}\text { Iron } \\
\mathrm{mg} \mathrm{L}^{-1}\end{array}$ & $\begin{array}{l}\text { Phosphate } \\
\mathrm{mg} \mathrm{L}^{-1}\end{array}$ & $\begin{array}{l}\text { Free } \\
\text { Ammonia } \mathrm{mg} \\
\mathrm{L}^{-1}\end{array}$ & $\begin{array}{l}\text { Nitrate } \\
\mathrm{mg} \mathrm{L}^{-1}\end{array}$ & $\begin{array}{l}\mathrm{BOD} \mathrm{Lg} \\
\mathrm{L}^{-1}\end{array}$ & $\begin{array}{l}\mathrm{DO} \\
\mathrm{mg} \mathrm{L}^{-1}\end{array}$ & $\begin{array}{l}\mathrm{Ph} \\
\begin{array}{l}\text { Temp. } \\
\left({ }^{\circ} \mathrm{C}\right)\end{array}\end{array}$ \\
\hline 1A & 0.02 & 0.150 & 0.007 & 0.40 & 1.320 & 7.11 & 6,59 & 26.0 \\
1B & & 1.000 & $0.090^{*}$ & 0.20 & 5.040 & 9.32 & 6,97 & 30.0 \\
1C & & $1.150 *$ & $1.540^{*}$ & 0.60 & $11.800 *$ & 10.64 & 9,00 & 31.0 \\
1D & & 0.800 & $0.500^{*}$ & 0.20 & 2.160 & 8.69 & 7,30 & 27.0 \\
2A & 0.19 & 0.020 & 0.007 & 0.30 & 0.920 & 5.67 & 7,14 & 27.0 \\
2B & & 0.150 & $0 ., 026$ & 0.30 & $7.840 *$ & 5.40 & 7,10 & 28.5 \\
2C & & 0.080 & $0.030 *$ & 0.10 & 4.860 & 7.59 & 7,39 & 28.0 \\
2D & & 0.080 & 0.007 & 0.40 & 0.900 & 5.08 & 6,69 & 28.0 \\
3A & 0.11 & $3.120 *$ & 0.007 & 0.10 & 5.220 & 7.21 & 6,11 & 29.0 \\
3B & & 0.270 & $0.140 *$ & 0.20 & $8.000 *$ & 11.78 & 8,34 & 29.0 \\
3C & & 0.600 & $0.270 *$ & 0.20 & $10.920 *$ & 12.20 & 8,61 & 28.0 \\
3D & & 0.170 & 0.007 & 0.30 & $7.100 *$ & 8.89 & 8,01 & 29.0 \\
\hline
\end{tabular}

Information:

*) values exceeding the permitted threshold for a class III water quality standard (fisheries allotment) in accordance with the Government Regulation no. 82 of 2001 
Rieski Ambarwati, Krisdianto, Slamat: Plankton Community Structure on Fish Ponds in The ...

Table 3. Correlation of plankton abundance with chemical and physical parameters of the ponds

\begin{tabular}{lllllllll}
\hline & $\begin{array}{l}\text { Free } \\
\text { Ammonia }\end{array}$ & Nitrate & Phosphate & DO & BOD & pH & Temp. & $\begin{array}{l}\text { Phytoplankton } \\
\text { Abundance }\end{array}$ \\
\hline Phytoplankton & 0.41 & -0.029 & 0.18 & $0.718^{*}$ & 0.553 & $0.579^{*}$ & $0.651^{*}$ & \\
Sig. & 0.186 & 0.929 & 0.575 & 0.009 & 0.062 & 0.049 & 0.022 & \\
Zooplankton & 0.208 & 0.027 & 0.048 & $0.628^{*}$ & $0.773^{*}$ & $0.59^{*}$ & 0.509 & $0.656^{*}$ \\
Sig. & 0.516 & 0.934 & 0.883 & 0.029 & 0.003 & 0.043 & 0.091 & 0.02 \\
\hline
\end{tabular}

* There is a significant correlation between variables (sig. $<0,05)$

The above results show a direct correlation between the abundance of phytoplankton with the $\mathrm{DO}, \mathrm{pH}$, and temperature. The correlation of phytoplankton abundance with $\mathrm{pH}$ was moderate, temperature and DO were in the strong category. The greater the $\mathrm{DO}$, temperature and $\mathrm{pH}$ values, the greater the abundance of the phytoplankton. This correlation is due to photosynthetic activities. Phytoplankton during the day binds a lot of $\mathrm{CO}^{2}$ for photosynthesis process. This condition causes increased water $\mathrm{pH}$ (Svobodava et al., 1993). Large abundance of phytoplankton when the blazing sunlight (high temperature) will increase the rate of photosynthesis. The rate of photosynthesis that is greater than the oxygen diffusion to the air causes high DO and oxygen supersaturation can occur.

Zooplankton has a direct correlation with $\mathrm{DO}, \mathrm{BOD}, \mathrm{pH}$, and phytoplankton abundance. The correlation of zooplankton abundance with $\mathrm{pH}$ was classified as moderate. Correlations with DO, BOD and phytoplankton are strong. Zooplankton productivity increases when ponds conditions support, ie the abundant availability of food (phytoplankton) and enough oxygen (DO). The high abundance and metabolism of zooplankton will increase the excretion results so that the $\mathrm{BOD}$ and $\mathrm{pH}$ values also increase.

From the following regression equations, the lowest sig value of the 3 regression models performed was selected (Table 4).

Table 4. Regression equation

\begin{tabular}{|c|c|c|c|}
\hline & Regression equations & $\mathbf{R}^{2}$ & Sig. \\
\hline Phytoplankt & n (phyto) Abundance & & \\
\hline Phosphate & In phyto $=7.578+11.414 \ln \left(\mathrm{PO}_{4}+1\right)-7.968 \ln \left(\mathrm{PO}_{4+1}\right)^{2}$ & 0.481 & 0.052 \\
\hline $\begin{array}{l}\text { Free } \\
\text { Amonia }\end{array}$ & $\begin{array}{l}\text { In phyto }=7.700+62.523 \ln \left(\mathrm{NH}_{4}+1\right)-222.493 \ln \left(\mathrm{NH}_{4}+1\right)^{2}+172.106 \\
\ln \left(\mathrm{NH}_{4}+1\right)^{3}\end{array}$ & $0.746^{*}$ & 0.009 \\
\hline Nitrate & $\begin{array}{l}\text { In phyto }=-4.018+213.435 \ln \left(\mathrm{NO}_{3}+1\right)-929.559 \ln \left(\mathrm{NO}_{3}+1\right)^{2}+ \\
1167.147 \ln \left(\mathrm{NO}_{3}+1\right)^{3}\end{array}$ & 0.58 & 0.062 \\
\hline DO & Ln phyto $=-3.539+5.986 \ln \mathrm{DO}$ & $0.516^{*}$ & 0.009 \\
\hline BOD & In phyto $=6.688+1.745 \ln (B O D+1)$ & 0.306 & 0.062 \\
\hline $\mathrm{pH}$ & In phyto $=-16.477+12.265 \ln \mathrm{pH}$ & $0 ., 335^{*}$ & 0.049 \\
\hline Temp. & In phyto $=-41.936-16.548 \ln$ temp $+4.515 \ln$ temp ${ }^{2}$ & 0.426 & 0.021 \\
\hline Zooplanktor & (zoo) abundance & & \\
\hline Phosphate & $\begin{array}{l}\ln z O O=1.513+31.825 \ln \left(\mathrm{PO}_{4}+1\right)-51.643 \ln \left(\mathrm{PO}_{4}+1\right)^{2}+21.161 \\
\ln \left(\mathrm{PO}_{4} \mathrm{X}+1\right)^{3}\end{array}$ & 0.341 & 0.102 \\
\hline $\begin{array}{l}\text { Free } \\
\text { Amonia }\end{array}$ & $\begin{array}{l}\ln z 00=3.181+62.105 \ln \left(\mathrm{NH}_{4}+1\right)-221.212 \ln \left(\mathrm{NH}_{4}+1\right)^{2}+169.129 \\
\quad \ln \left(\mathrm{NH}_{4}+1\right)^{3}\end{array}$ & $0.66^{*}$ & 0.028 \\
\hline Nitrate & $\begin{array}{l}\ln \text { zoo }=-11.498+230.199 \ln \left(\mathrm{NO}_{3}+1\right)-919.433 \ln \left(\mathrm{NO}_{3}+1\right)^{2}+ \\
1081.107 \ln \left(\mathrm{NO}_{3}+1\right)^{3}\end{array}$ & 0.494 & 0.124 \\
\hline DO & $\ln z 00=-6.358+5.136 \ln \mathrm{DO}$ & $0.394^{*}$ & 0.029 \\
\hline BOD & $\ln z o o=0.913+2.393 \ln (B O D+1)$ & $0.598^{*}$ & 0.003 \\
\hline $\mathrm{pH}$ & $\ln z o o=-21.192+12.279 \ln \mathrm{pH}$ & $0.349^{*}$ & 0.043 \\
\hline Temp. & In zoo $=-74.011+23.364 \ln$ temp & 0.259 & 0.091 \\
\hline Phyto & In zoo $=-1,262+0,644$ In phyto & $0.431^{*}$ & 0.020 \\
\hline
\end{tabular}

${ }^{*}$ There is a significant correlation between variables (sig. $\left.<0,05\right)$

The greatest correlation is the ammonia of $74.6 \%$, described in the curve. $1 \mathrm{~B}, 1 \mathrm{C}, 2 \mathrm{C}$, $3 \mathrm{~B}$ and $\mathrm{BC}$ ponds contain high free-ammonia accompanied by a high abundance of phytoplankton (> 15,000 L-1 cells). The 1D pond with free ammonia concentration of $0.5 \mathrm{mg} \mathrm{L}^{-1}$ only has phytoplankton abundance of $4,464 \mathrm{~L}^{-1}$ cells. In accordance with Slamat (2015), whose 
studying plankton fertility in the monotonous swamps (Hulu Sungai Utara), a typical swamp water with high ammonia $\left(0.15-0.26 \mathrm{mgL}^{-1}\right)$ has a various phytoplankton abundance around 328 - 7600 cells $\mathrm{L}^{-1}$. Elevated levels of free ammonia, nitrates and phosphates do not necessarily indicate high phytoplankton productivity. This condition also occurs in Djuanda reservoir (Kartamiharja, 2007). The value of $\mathrm{N}$ and $\mathrm{P}$ elements in the Djuanda reservoir is high, but not in line with the abundance of phytoplankton. The N:P ratio can be a limiting factor for phytoplankton productivity. Most algae grows optimally at an $N: P$ ratio of 10:1. Phosphorus becomes a limiting factor when the ratio is greater than $10: 1$, whereas at a ratio smaller than $5: 1$, nitrogen becomes the limiting factor of phytoplankton growth (Schindler, 1978).

Zooplankton has a significant correlation with the abundance of phytoplankton, free ammonia, DO and BOD. The greatest correlation is with free ammonia, which is $66 \%$ (cubic). Ammonia in the ponds can be derived from the rest of the metabolism of fish and zooplankton and decomposition of organic material by bacteria. The high abundance of zooplankton can cause increased ammonia. High ammonia is also associated with increased phytoplankton so that zooplankton productivity also increases. This compound is also toxic to zooplankton and fish. Ammonia concentrations that exceed the zooplankton tolerance limits inhibit zooplankton productivity.

\section{The Fertility of The Fish-Farming Ponds}

The parameters used to assess the ponds fertility are visibility (secchi disc), nitrate concentration $\left(\mathrm{NO}_{3}-\right.$ ), phosphate concentration $\left(\mathrm{PO}_{4}{ }^{3-}\right)$ and abundance of plankton. These values can be seen in Table 5 .

Table 5. Ponds fertility assessment

\begin{tabular}{|c|c|c|c|c|}
\hline Sample Code & $\begin{array}{c}\text { Plankton Abundance } \\
\left.\text { (phyto + zoo) (cell/ind. } L^{-1}\right)\end{array}$ & $\begin{array}{l}\text { Phosphate } \\
\left(\mathrm{mg} \mathrm{L}^{-1}\right)\end{array}$ & $\begin{array}{l}\text { Nitrate } \\
\left(\mathrm{mg} \mathrm{L}^{-1}\right)\end{array}$ & $\begin{array}{l}\text { Visibility } \\
(\mathrm{m})\end{array}$ \\
\hline $1 \mathrm{~A}$ & 1,665 & 0.150 * & 0.40 * & 0.44 * \\
\hline 1B & $1,421,275$ * & 1.000 * & 0.20 * & 0.42 * \\
\hline $1 \mathrm{C}$ & 166,396 * & 1.150 * & 0.60 * & 0.35 * \\
\hline $1 \mathrm{D}$ & 4,490 & 0.800 * & 0.20 * & 0.32 * \\
\hline $2 A$ & 5,812 & 0.020 & 0.30 * & 1.37 * \\
\hline $2 B$ & 3,884 & 0.150 * & 0.30 * & - \\
\hline $2 \mathrm{C}$ & 20,212 * & 0.080 * & 0.10 & - \\
\hline $2 \mathrm{D}$ & 1,974 & 0.080 * & 0.40 * & 0.52 * \\
\hline $3 A$ & 1,954 & 3.120 * & 0.10 & - \\
\hline 3B & 113,980 * & 0.270 * & 0.20 & - \\
\hline $3 C$ & 75,176 * & 0.600 * & 0.20 & - \\
\hline $3 D$ & 8,846 & 0.170 * & 0.30 * & - \\
\hline
\end{tabular}

Information:

*) indicates the values belong to the eutrophic category

$1 \mathrm{~B}$ and $1 \mathrm{C}$ ponds that located at BBAT Mandiangin meet all of the eutrophic criteria. $2 \mathrm{C}, 3 \mathrm{~B}$ and $3 \mathrm{C}$ ponds also classified to the eutrophic when viewed from plankton abundance and phosphate values. The levels of $2 \mathrm{C}, 3 \mathrm{~B}$ and $3 \mathrm{C}$ ponds water ammonia exceed the threshold value of the class III water quality standard, which is $>0.02 \mathrm{mg} \mathrm{L}^{-1}$. The physical condition of eutrophic ponds suggests fertility by plankton. These ponds appear to be greener in color than other ponds in the vicinity. Mesotrophic fertility rates occur in Mandiangin's BBAT outlet (1D), pond/inlet channel (2A), papuyu's pond (2B) at BB-IAT Karang Intan and Cindai Alus catfish pond (3D). The inlet channel
(1A) BBAT Mandiangin, the outlet pond (2D) BB-IAT Karang Intan and inlet pond (3A) in Cindai Alus belong to the oligotrophic category. The type of plankton found in 1B, 1C, 2C, 3B and $3 \mathrm{C}$ ponds supports eutrophic status. There are Aulacoseira granulata, Scenedesmus sp., Microcystis sp., Anabaena sp., And Anuraeopsis fissa in 1B pond. Several types of Scenedesmus and Anabaena are found in the $1 \mathrm{C}$ pond. In the $2 \mathrm{C}$ pond, there were found Aulacoseira granulata, Coelastrum, Scenedesmus, Pediastrum, Oscilatoria, and Microcystis in abundance. 3B and 3C ponds are adjacent and there is a considerable connection between the ponds, resulting in the exchange of 
water and organisms in the ponds. Aulacoseira granulata, Coelastrum, Pediastrum, Microcystis, Oscilatoria and Branchionus angularis are found in both ponds.

The fertility of plankton in $1 \mathrm{~B}$ pond is dominated by Aulacoseira granulata which is also found in abundance in $1 \mathrm{C}, 2 \mathrm{C}, 3 \mathrm{~B}$ and $3 \mathrm{C}$ ponds. Aulacoseira granulata belongs to the Bacillarophyta division, growing rapidly if there are elements abundance of nitrogen, phosphorus and silica. These diatoms include eutrophic water bioindicators (Bellinger \& Sigee, 2010; Goldenberg \& Lehman, 2012; Samudra et al., 2013). The abundance of Aulacoseira granulata is also due to its high aggregation ability to form long chains (Vieira et al., 2008). Long chains can keep them from zooplankton grazing. This species can also avoid too strong sunlight by drowning (Reynold, 2006).

Other eutrophic ponds are dominated by Cyanophyta, namely Microcystis, Anabaena and Oscilatoria. Cyanophyta can grow massively on the surface of the water, forming a layer of biomass, competing with other algae and can cause problems for zooplankton and fish populations. Dominance by Cyanophyta in $1 \mathrm{C}, 2 \mathrm{C}, 3 \mathrm{~B}$ and $3 \mathrm{C}$ ponds is thought to be caused by low light and high $\mathrm{pH}$ tolerance; resistant to zooplankton grazing; as well as symbiosis with aerobic bacteria for $\mathrm{N}$ fixation from the atmosphere (Bellinger \& Sigee, 2010).

\section{CONCLUSION}

The structure of the plankton communities in each pond is different. The abundance of phytoplankton has a significant correlation with $\mathrm{pH}$, temperature, $\mathrm{DO}$, and free ammonia. The abundance of zooplankton also has a significant correlation with $\mathrm{pH}, \mathrm{DO}, \mathrm{BOD}$, and free ammonia. The seeds pond at BBAT Mandiangin is eutrophically dominated by Bacillarophyta and Amoboezoa, while in BB-IAT Karang Intan and Cindai Alus are dominated by Cyanophyta and Rotifera. The inlet channels of BBIAT Karang Intan and the broodstock pond are mesotrophic, predominant by Cyanophyta, Chlorophyta and Rotifer. BB-IAT Karang Intan outlet ponds, BBAT Mandiangin inlet channel and inlet pond in Cindai Alus are included in the oligotrophic category, which is predominantly by Cyanophyta and Chlorophyta. The plankton community structure of the fish-farming ponds varies even with the same ecological conditions.

\section{REFERENCES}

Bellinger, E.G. \& Sigee, D.C. (2010). Freshwater Algae: Identification and Use as Bioindicators. WilleyBlackwell. UK.

Dhargalkar, V.K. \& Ingole, B.S. (2004). Phytoplankton Identification Manual. National Institute of Oceanography. New Delhi.

Edmondson, W.T. (1959). Freshwater Biology. Edisi ke-2. University of Washington. Seattle.

Goldenberg, S.Z. \& Lehman, J.T. (2012). Diatom Response to the Whole Lake Manipulation of a Eutrophic Urban Impoundment. Hydrobiologia. Pp 685.

Government Regulation of the Republic of Indonesia (PP) (2001). No. 82 on Water Quality Management and Water Pollution Control. Jakarta.

Kartamiharja, E.S. (2007). Spectra of Plankton Biomass Size and Its Utilization Potential for Fish Communities in the Limnetic Zone of The Ir.H. Djuanda Reservoir, West Java. Graduate School Dissertation. Bogor Agricultural University. Bogor.

Kouassi, B.A.T., M.P Adon, K. Komoe, \& A. Ouattara (2015). Cyanobacteria from a Shallow Reservoir in Cote d'Ivoire. Journal of Biodiversity and Environmental Sciences 7: 136-149.

Liu, J. \& Vyverman, W. (2014). Differences in Nutrient Uptake Capacity of The Bentic Filamentous Algae Cladophora sp., Klebsormidium sp. and Pseudanabaena sp. Under Varying N/P Conditions. Bioresource Technology 179: 234-242.

Patten, P.V., Y. Li, \& G. H. Wikfors (2012). A Student's Guide to Common Phytoplankton of long Island Sound. Connecticut Sea Grant College Program. Connecticut.

Phan-doan-dang, Nguyen-van-khoi, Le-thinguyet-nga, Dang-ngoc-thanh, \& Hothanh-hai (2015). Identification Handbook of Freshwater Zooplankton of the Mekong River and its Tributaries. Mekong River Commission. Vientiane.

Regulating Phytoplankton Production and Standing Crop in The World's Freshwaters. Limnol. Oceanogr 23: 478-486. 
Rieski Ambarwati, Krisdianto, Slamat: Plankton Community Structure on Fish Ponds in The ...

Reynolds, C.S. (2006). The Ecology of Phytoplankton. Cambrige University Press. USA.

Samudra, S.R., T. R. Soeprobowati, \& M. Izzati. (2013). Composition, Abundance and Diversity of The Rawa Pening Lake Phytoplankton of Semarang Regency. Bioma 15: 6-13.

Slamat (2015). Plankton Fertility in Supporting Fish Productivity in Monotonous Swamp in Hulu Sungai Utara Regency. Tropical Weatland Journal. 1: 25-31.

Vieira, A.A.H., P.I.C. Ortolano, D. Giraldo, M.J. D. Olieveira, T. B. Bittar, A.T. Lombardi, \& A.L. Sartori (2008). Role of Hydrophobic Extracellular Polysaccharide of Aulacoseira granulate (Bacillariophyceae) on Aggregate Formation in a Turbulent and Hypereutrophic Reservoir. Limnol Oceanogr 53: 1887-1899.

Vuuren, S.J. van, J. Taylor, C. van Ginkel, \& A. Gerber (2006). Easy Identification of The Most Common Freshwater Algae. A Guide for The Identification of Microscopic Algae in South African Freshwaters. North-West University and Departement of Water Affairs and Forestry. Potchefstroom.

Witty, L.M. (2004). Practical Guide to Identifying Freshwater Crustacean Zooplankton. Cooperative Freshwater Ecology Unit. Canada. 